\title{
KORELASI ANTARA SIKAP PADA MATA PELAJARAN BIOLOGI DAN KECERDASAN EMOSIONAL DENGAN HASIL BELAJAR BIOLOGI SISWA KELAS XI MIPA SMAN 3 KOTA TASIKMALAYA
}

\author{
Reni Nur Aeni ${ }^{1}$, Endang Surahman ${ }^{2}$, Ryan Ardiansyah ${ }^{3}$ \\ 1,2,3 Jurusan Pendidikan Biologi, FKIP, Universitas Siliwangi, Tasikmalaya \\ e-mail: ${ }^{1}$ reninuraeni522016@gmail.com
}

\begin{abstract}
ABSTRAK
Tujuan dari penelitian ini yaitu: (1) untuk mengetahui hubungan antara sikap dengan hasil belajar biologi peserta didik; (2) untuk mengetahui hubungan antara kecerdasan emosional dengan hasil belajar biologi peserta didik; (3) untuk mengetahui hubungan antara sikap pada mata pelajaran biologi dan kecerdasan emosional dengan hasil belajar biologi peserta didik. Metode penelitian yang digunakan adalah studi korelasional. Populasi dalam penelitian ini yaitu seluruh kelas XI MIPA di SMA Negeri 3 Kota Tasikmalaya. Pengambilan sampel dilakukan secara purposive sampling sebanyak satu kelas yaitu kelas XI MIPA 4 berjumlah 36 peserta didik. Teknik pengumpulan data dilakukan dengan pengisian kuesioner pada google form, untuk kuesioner sikap pada mata pelajaran biologi berjumlah 28 butir pernyataan yang mengacu pada TOSRA (Test of Science-Related Attitude) dan kuesioner kecerdasan emosional mengadopsi dari SSEIT (Schutte Self Emotional Intelligence Test) berjumlah 33 butir pernyataan. Teknik analisis data yang digunakan adalah uji korelasi sederhana dan uji korelasi berganda dengan $\alpha 0,05$. Hasil penelitian menunjukkan bahwa ada korelasi positif antara sikap pada mata pelajaran biologi dengan hasil belajar biologi dengan koefisien korelasi sebesar 0,547 dan korelasi antara kecerdasan emosional dengan hasil belajar biologi juga berhubungan positif dengan koefisien korelasi sebesar 0,487 serta korelasi antara sikap pada mata pelajaran biologi dan kecerdasan emosional secara bersamasama dengan hasil belajar memiliki hubungan yang positif dengan koefisen korelasi sebesar 0,536 . Disimpulkan bahwa terdapat hubungan yang positif dan signifikan antara sikap pada mata pelajaran biologi dan kecerdasan emosional dengan hasil belajar biologi peserta didik baik secara masing-masing variabel $\mathrm{X}$ dengan variabel $\mathrm{Y}$ maupun secara simultan di kelas XI MIPA SMA Negeri 3 Kota Tasikmalaya.
\end{abstract}

Kata Kunci: Korelasional; Sikap pada Mata Pelajaran Biologi; Kecerdasan Emosional; Hasil Belajar Biologi

\section{ABSTRACT}

The aim of this study is: (1) to know the relationship between attitudes in biology subjects with biology learning outcomes of students; (2) to know the relationship between emotional intelligence with the biology learning outcomes of students; (3) to know the relationship between attitudes in biology subjects and emotional intelligence with the biology learning outcomes of students. The research method used is a correlational study. The population in this study were all class XI MIPA in SMA Negeri 3 Kota Tasikmalaya. The sampling technique used was purposive sampling. One sample class was selected, namely class XI MIPA 4, which amounted to 36 students. The data collection technique was carried out by filling in a questionnaire on the google form, for the attitude questionnaire in biology subjects totaling 28 statements referring to the TOSRA (Test of Science-Related Attitude) and the emotional intelligence questionnaire adopted from SSEIT (Schutte Self Emotional 
Intelligence Test) totaling 33 statement items. The data analysis technique used was simple correlation test and multiple correlation test with $\alpha 0.05$. The results showed that there was a positive correlation between attitudes in biology subjects and biology learning outcomes with a correlation coefficient of 0.547 and the correlation between emotional intelligence and biology learning outcomes was also positively related to a correlation coefficient of 0.487 and a correlation between attitudes in biology and emotional intelligence subjects. jointly with learning outcomes have a positive relationship with a correlation coefficient of 0.536. It is concluded that there is a positive and significant relationship between attitudes in biology and emotional intelligence subjects with the biology learning outcomes of students, both in X and Y variables and simultaneously in class XI MIPA SMA Negeri 3 Kota Tasikmalaya.

Keywords: Correlational; Attitudes in Biology Subjects; Emotional Intelligence; Biology Study Results

\section{PENDAHULUAN}

Cepat lambatnya proses belajar salah satunya dipengaruhi oleh sikap. Sikap memiliki peranan dalam terwujudnya tujuan pembelajaran (Rijal dan Bachtiar, 2015). Sikap sendiri terdiri atas perasaan mendukung atau tidak mendukung terhadap suatu objek yang dihadapi (Saifuddin, Azwar, 2017). Sikap dapat diartikan sebagai kecenderungan individu untuk menanggapi dengan cara suka atau tidak suka berkenaan dengan suatu objek tertentu.

Selain aspek sikap, diperlukan suatu kombinasi lain yang berhubungan dengan kepribadian yaitu kecerdasan emosional. Craggs (2005:1) menjelaskan "Hasil dan temuan banyak penelitian mengungkapkan bahwa IQ hanya berperan kecil dalam prestasi akademik peserta didik." Ada faktor lain yang memiliki peranan penting untuk mencapai keberhasilan peserta didik dalam belajar yaitu kecerdasan emosional (Rampisela, Deisa Iriani, dkk, 2017).

Berdasarkan hasil observasi terhadap pembelajaran biologi di kelas XI MIPA SMAN 3 Kota Tasikmalaya terdapat kesulitan belajar biologi di mana berdasarkan data hasil ujian akhir semester pada mata pelajaran biologi didapatkan nilai peserta didik masih banyak yang belum mencapai KKM. Berdasarkan teori dan penelitian sebelumnya yang serupa, penulis berasumsi bahwa hal ini dapat disebabkan karena beberapa faktor yaitu sikap peserta didik pada mata pelajaran biologi dan kecerdasan emosional peserta didik. Selain itu, hasil wawancara dengan guru biologi di SMAN 3 Kota Tasikmalaya bahwa aspek yang diukur dalam prestasi akademik hanya berkaitan dengan IQ atau nilai kognitif saja dan belum pernah dilakukan pengukuran aspek lainnya yang sejatinya memiliki kontribusi juga terhadap hasil belajar seperti sikap, kecerdasan emosional, dan sebagainya. Maka kecerdasan emosional dihubungkan dengan sikap pada mata pelajaran biologi akan menjadi suatu kombinasi yang baik dalam meraih hasil belajar sehingga perlu dilakukan penelitian lebih lanjut.

\section{METODE}

Metode penelitian yang digunakan dalam penelitian ini adalah korelasional. Populasi dalam penelitian ini adalah keseluruhan kelas XI MIPA SMAN 3 Kota Tasikmalaya yang berjumlah enam kelas dengan jumlah peserta didik sebanyak 208 orang. Dari populasi sebanyak 6 kelas, diambil sampel sebanyak satu kelas menggunakan teknik Purposive sampling, di mana dipilih kelas yang memiliki nilai rata-rata tinggi untuk dijadikan sampel. Dalam penelitian ini kelas yang dijadikan sampel penelitian yaitu kelas XI MIPA 4, kelas tersebut memiliki nilai rata-rata akademik yang tinggi sehingga dimungkinkan memiliki sikap positif terhadap mata pelajaran biologi dan kecerdasan emosional yang baik. Desain penelitian yang digunakan dalam penelitian ini adalah desain korelasional berganda. 
Instrumen yang digunakan untuk mengukur sikap pada mata pelajaran biologi yaitu menggunakan kuesioner yang mengacu pada dimensi sikap dalam Test of Science related attitude (TOSRA) oleh Fraser (1982) yang terdiri atas 7 dimensi sikap. Peneliti mengambil semua dimensi sikap tersebut kemudian instrumennya direduksi oleh peneliti dimana hanya diambil beberapa pernyataan yang sesuai dengan variabel penelitian. Dari setiap dimensi sikap yang awalnya terdiri atas 5 pernyataan positif dan 5 pernyataan negatif hanya di ambil 2 pernyataan positif dan 2 pernyataan negatif dari setiap dimensi sikap. Instrumen sikap ini telah divalidasi dan layak digunakan berdasarkan hasil expert judgment dan uji coba instrumen.

Instrumen untuk mengukur kecerdasan emosional peneliti mengadaptasi keseluruhan dari instrumen SSEIT (Schutte self reprot emotional Intelligence test) yang sudah tervalidasi dalam penelitian Nicola S. Schutte et. al tahun 1998, dengan dialih bahasa dari bahasa inggris ke bahasa Indonesia. SSEIT memiliki 4 indikator dengan 33 butir pernyataan.

Instrumen untuk mengukur hasil belajar biologi peserta didik dibuat oleh Guru mata pelajaran biologi kelas XI MIPA di SMAN 3 Kota Tasikmalaya sehingga sudah teruji tingkat keabsahan dan kepercayaannya, hasi; belajar ini diambil dari ulangan harian pada konsep jaringan tumbuhan tahun ajaran 2020/2021.

\section{HASIL DAN PEMBAHASAN}

Uji Korelasi Sikap pada Mata Pelajaran Biologi $\left(X_{1}\right)$ dengan Hasil Belajar Biologi (Y)

Berdasarkan pada tabel 1 dapat diketahui bahwa besarnya hubungan antara sikap pada mata pelajaran biologi dengan hasil belajar biologi adalah $0,547\left(\boldsymbol{r}_{\mathbf{1}} \boldsymbol{y}=\right.$ $0,547)$. Untuk menguji signifikansi terlihat nilai Sig. (2-tailed) sebesar 0,001 yang berarti nilai tersebut kurang dari 0,05 artinya terdapat hubungan yang signifikan antara sikap pada mata pelajaran biologi dengan hasil belajar biologi.

Tabel 1. Hasil Uji Korelasi antara Sikap pada Mata Pelajaran Biologi dengan Hasil Belajar Biologi

\begin{tabular}{llll}
\hline \multicolumn{1}{c}{ Correlations } \\
\hline & SIKAP PADA & HASIL \\
& & MATA & BELAJAR \\
& & PELAJARAN & BIOLOGI \\
& BIOLOGI & \\
SIKAP PADA MATA & Pearson Correlation & 1 & $.547^{* *}$ \\
PELAJARAN BIOLOGI & Sig. (2-tailed) & & .001 \\
& $\mathrm{~N}$ & 36 & 36 \\
HASIL BELAJAR & Pearson Correlation & $.547^{* *}$ & 1 \\
BIOLOGI & Sig. (2-tailed) & .001 & \\
& $\mathrm{~N}$ & 36 & 36 \\
$* *$. Correlation is significant at the 0.01 level (2-tailed). & \\
\hline
\end{tabular}

Sumber: Hasil pengolahan data uji korelasi dengan SPSS versi 25 for windows

Uji Korelasi Kecerdasan Emosional $\left(\mathrm{X}_{2}\right)$ dengan Hasil Belajar Biologi (Y)

Berdasarkan pada tabel 2 dapat diketahui bahwa besarnya hubungan antara kecerdasan enmosional dengan hasil belajar biologi adalah 0,487 $\left(\boldsymbol{r}_{2} \boldsymbol{y}=0,487\right)$. Untuk menguji signifikansi terlihat nilai Sig. (2-tailed) sebesar 0,003 yang berarti nilai tersebut kurang dari 0,05 artinya terdapat hubungan yang signifikan antara 
kecerdasan emosional dengan hasil belajar biologi.

Tabel 2. Hasil Uji Korelasi antara Kecerdasan Emosional dengan Hasil Belajar Biologi

\begin{tabular}{|c|c|c|c|}
\hline \multicolumn{4}{|c|}{ Correlations } \\
\hline & & HASIL & KECERDASA \\
\hline & & BELAJAR & $\mathrm{N}$ \\
\hline & & BIOLOGI & EMOSIONAL \\
\hline HASIL BELAJAR & Pearson Correlation & 1 & $.487^{* *}$ \\
\hline \multirow[t]{2}{*}{ BIOLOGI } & Sig. (2-tailed) & & .003 \\
\hline & $\mathrm{N}$ & 36 & 36 \\
\hline KECERDASAN & Pearson Correlation & $.487^{* *}$ & 1 \\
\hline \multirow[t]{2}{*}{ EMOSIONAL } & Sig. (2-tailed) & .003 & \\
\hline & $\mathrm{N}$ & 36 & 36 \\
\hline$* *$. Correlation is s & tt at the 0.01 level (2- & ed). & \\
\hline
\end{tabular}

Uji Korelasi Sikap pada Mata Pelajaran Biologi $\left(X_{1}\right.$ dan Kecerdasan Emosional $\left(X_{2}\right)$ dengan Hasil Belajar Biologi (Y)

Berdasarkan pada tabel 3 dapat diketahui bahwa nilai signifikansi $\mathrm{F}$ change sebesar 0,000 yang berarti nilai tersebut < 0,05 artinya terdapat hubungan yang signifikan antara sikap pada mata pelajaran biologi dan kecerdasan emosional dengan hasil belajar biologi. Nilai $\mathrm{R}$ (koefisien korelasi) diperoleh sebesar 0,732 dan nilai $\mathrm{R}$ square (koefisien determinasi) sebesar 0,536 .

Tabel 3. Hasil Uji Korelasi antara Sikap pada Mata Pelajaran Biologi dan Kecerdasan Emosional dengan Hasil Belajar Biologi

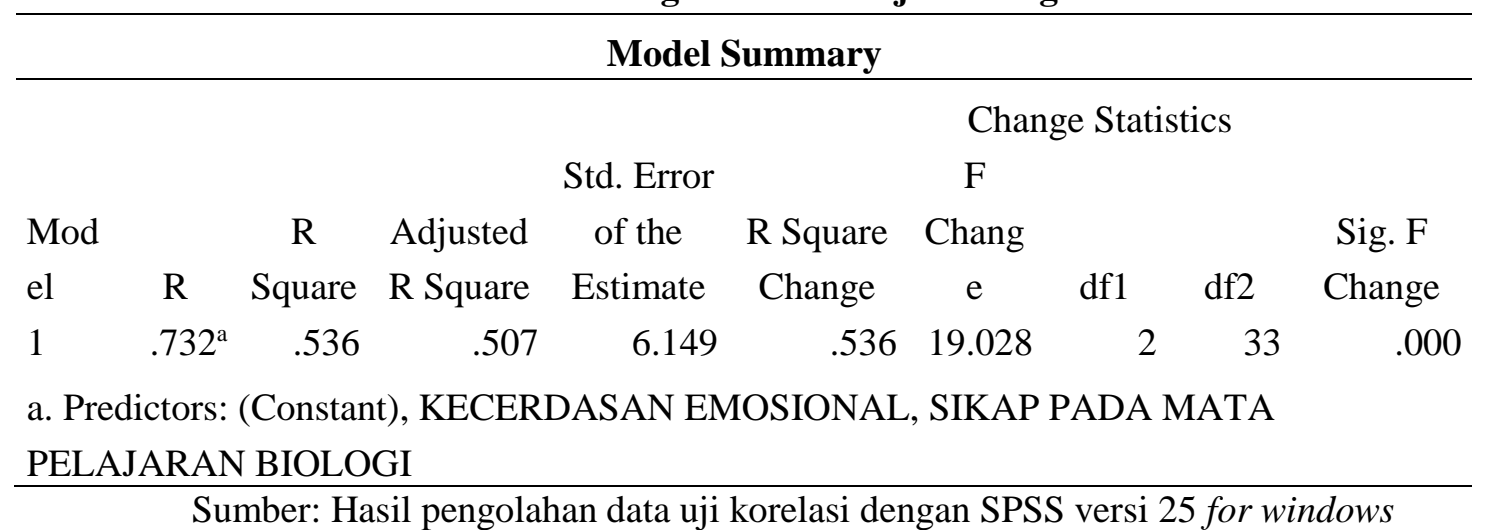

\section{Hubungan Sikap pada Mata Pelajaran Biologi dengan Hasil Belajar Biologi}

Berdasarkan hasil analisis dengan uji korelasi pearson dengan menggunakan SPSS 25 for windows, menunjukan terdapat hubungan yang positif dan signifikan antara sikap pada mata pelajaran biologi dengan hasil belajar biologi ditunjukan dari besarnya nilai signifikansi sebesar 0,001 dengan menggunakan taraf signifikansi $5 \%$ maka dasar pengambilan keputusannya yaitu terdapat korelasi dikarenakan $0,001 \leq 0,05$.

Hasil uji korelasi ini menunjukan bahwa sikap pada mata pelajaran biologi berkorelasi positif dengan hasil belajar biologi. Hal ini mengandung makna bahwa semakin baik sikap peserta didik pada mata pelajaran biologi maka makin baik hasil belajar biologinya. Hasil analisis ini membuktikan bahwa rasa suka atau ketidaksukaan seseorang terhadap suatu 
objek akan mempengaruhi hasil yang diperolehnya. Penelitan yang dilakukan oleh Rijal dan Bachtiar (2015) juga terdapat korelasi yang positif antara sikap dengan hasil belajar biologi. Selain itu, penelitian yang sama juga dilakukan oleh Soleha (2018) bahwa terdapat hubungan antara sikap dengan hasil belajar, namun pada mata pelajaran matematika.

Maka dari itu dapat disimpulkan bahwa sikap pada mata pelajaran biologi dengan hasil belajar biologi berkorelasi positif. Semakin tinggi atau baik sikap peserta didik pada mata pelajaran biologi maka hasil belajar biologi akan semakin tinggi atau baik pula.

\section{Hubungan Kecerdasan Emosional dengan Hasil Belajar Biologi}

Berdasarkan hasil analisis dengan uji korelasi pearson dengan menggunakan SPSS 25 for windows, menunjukan terdapat hubungan yang positif dan signifikan antara kecerdasan emosional dengan hasil belajar biologi ditunjukkan dari besarnya nilai signifikansi sebesar 0,003 dengan menggunakan taraf signifikansi $5 \%$ maka dasar pengambilan keputusannya yaitu terdapat korelasi dikarenakan $0,003 \leq 0,05$. Hasil uji korelasi tersebut menunjukkan bahwa kecerdasan emosional berkorelasi positif dengan hasil belajar biologi yang berarti semakin tinggi tingkat kecerdasan emosional peserta didik maka semakin tinggi juga hasil belajar biologinya.

Penelitian yang dilakukan oleh Syarif dan Haris Munandar (2017:45) juga terdapat korelasi yang positif antara kecerdasan emosional dengan hasil belajar peserta didik namun dengan nilai signifikansi sebesar 0,000. Selain itu, penelitian yang sama dilakukan oleh Ventini dan Sukardjo (2018:179) bahwa terdapat hubungan yang positif dan signifikan antara kecerdasan emosional dengan hasil belajar pada mata pelajaran matematika dengan nilai signifikansi 0,000 .

Salah satu faktor yang mempengaruhi hasil belajar adalah faktos psikologis
(Suryabrata, 1989:6). Kecerdasan emosional termasuk salah satu faktor psikologis tersebut yang merupakan faktor dari dalam diri peserta didik dimana kecerdasan emosional memiliki peranan dalam pencapaian hasil belajar peserta didik, maka ketika peserta didik mampu menggunakan dan mengendalikan emosi dengan baik dan benar artinya peserta didik memiliki kecerdasan emosi yang tinggi maka akan dapat meraih hasil belajar yang tinggi, begitupula sebaliknya.

\section{Hubungan Sikap pada Mata Pelajaran Biologi dan Kecerdasan Emosional dengan Hasil Belajar Biologi}

Pengujian hipotesis yang ke tiga yaitu untuk menguji sikap pada mata pelajaran biologi dan kecerdasan emosional secara simultan dengan hasil belajar biologi. Hasil pengujian ini bahwa terdapat hubungan antara dua variabel bebas dengan variabel terikat tersebut. Hal ini terlihat dari nilai signifikansi $F$ change sebesar 0,000 yang berarti nilai tersebut $<0,05$ artinya terdapat hubungan yang signifikan antara sikap pada mata pelajaran biologi dan kecerdasan emosional dengan hasil belajar biologi.

Makna dari pengujian hipotesis ketiga ini adalah bahwa ketika peserta didik memiliki sikap pada mata pelajaran biologi dan kecerdasan emosional yang baik atau tinggi secara bersama-sama maka akan memperoleh hasil belajar biologi yang baik atau tinggi, dan sebaliknya. Sebagaimana hasil penelitian Ventini dan Sukardjo (2018:179) bahwa terdapat hubungan yang positif dan signifikan antara sikap pada mata pelajaran matematika dan kecerdasan emosional secara bersama-sama dengan hasil belajar matematika.

Hasil penelitian ini sejalan dengan ungkapan ahli yaitu menurut Suryabrata (1989:6) bahwa secara garis besar faktorfaktor yang mempengaruhi hasil belajar dapat digolongkan menjadi dua bagian yaitu faktor internal dan eksternal, dimana salah satu faktor internal terdapat faktor psikologis (kecerdasan emosional, sikap, dll). Dengan demikian hasil penelitian ini 
sejalan dengan teori tersebut bahwa sikap pada mata pelajaran biologi dan kecerdasan emosional yang keduanya merupakan faktor internal yang mempengaruhi hasil belajar sehingga terdapat hubungan antara variabel bebas dengan variabel terikat.

Adanya hubungan yang positif dan signifikan disebabkan karena adanya sikap peserta didik yang positif. Artinya jika peserta didik memiliki sikap positif yang tinggi terhadap pelajaran, dalam penelitian ini khususnya pelajaran biologi maka semakin tinggi pula pencapaian hasil belajar peserta didik. Sebaliknya semakin rendah respon positif peserta didik (semakin tinggi respon negatif) maka semakin rendah pula pencapaian hasil belajar peserta didik.

Peserta didik dengan kecerdasan emosional yang tinggi maka akan lebih mudah berinteraksi dengan orang lain dan dapat aktif mengikuti kegiatan belajar baik di dalam kelas maupun di luar kelas yang hal tersebut akan membantu peserta didik mencapai hasil belajar biologi yang lebih baik.

Dari uraian di atas dapat disimpulkan bahwa sikap pada mata pelajaran biologi

\section{KESIMPULAN}

Terdapat hubungan yang positif dan signifikan antara sikap pada mata pelajaran biologi dengan hasil belajar biologi peserta didik, dengan nilai signifikansi sebesar 0,001 dan koefisien korelasi $\left(\boldsymbol{r}_{\mathbf{1}} \boldsymbol{y}\right)$ sebesar 0,547 .

Selain itu, antara kecerdasan emosional dengan hasil belajar biologi peserta didik juga memiliki hubungan yang positif dan signifikan, dengan nilai signifikansi sebesar 0,003 dan koefisien korelasi $\left(\boldsymbol{r}_{2} \boldsymbol{y}\right)$ sebesar 0,487.

Antara sikap pada mata pelajaran biologi dan kecerdasan emosional dengan hasil belajar biologi peserta didik juga memiliki hubungan yang positif dan signifikan, dengan nilai signifikansi sebesar 0,000 dan koefisien korelasi (R) sebesar 0,732 . dan kecerdasan emosional merupakan faktor penting yang harus diperhatikan oleh peserta didik untuk meraih hasil belajar biologi yang lebih baik. Ketika peserta didik memiliki sikap positif pada mata pelajaran biologi atau dengan kata lain menyenangi mata pelajaran biologi maka akan meningkatkan intensitas belajar biologi, disamping memiliki sikap yang positif pada mata pelajaran biologi namun ketika diiringi juga dengan memiliki kecerdasan emosional yang tinggi di mana peserta didik mampu memahami emosi diri dan orang lain sehingga hal ini dapat membantu peserta didik mencapai hasil belajar biologi yang lebih baik.

Selain harus diperhatikan oleh peserta didik, pendidik atau guru pun harus memperhatikan faktor-faktor yang mempengaruhi hasil belajar seperti menggunakan strategi, media dan metode pembelajaran yang relevan dan sesuai, baik sesuai dengan materi mapun sesuai dengan kebutuhan peserta didik. Selain itu guru juga dapat memberikan motivasi sehingga dapat menimbulkan semangat belajar kepada peserta didik.

\section{DAFTAR PUSTAKA}

Azwar, Saifuddin. (2007). Sikap Manusia Teori dan Pengukurannya. Yogyakarta: Pustaka Pelajar.

Craggs, J.G. 2005. Developing a Coherent Model of Intelligence: A Mechanism for Understanding Neurolinguistic Processing.PhD Thesis. University of Georgia. Retrieved December 12, 2018 from http://plaza.ufl.edu/jcraggs/Craggs_ Jason_G_2005May_PhD.pdf

Fraser, Barry J. (1982). Test of ScienceRelated Attitudes. Australia: Allaby Press. Retrivied from http://stelar.edc.org/instruments/test -science-related-attitudes-tosra 
Rampisela, Deisa Iriani, dkk. (2017). Hubungan Kecerdasan Emosional Dan Kecerdasan Spiritual Dengan Prestasi Belajar Siswa Di Smp Katolikst. Fransiskus Pineleng. EJurnal Keperawatan. 5(1). Diakses dari https://ejournal.unsrat.ac.id/index.p $\mathrm{hp} / \mathrm{jkp} /$ article/view/14895

Rijal, Syamsu dan Suhaedir Bachtiar. (2015). Hubungan antara Sikap, Kemandirian Belajar, dan Gaya Belajar dengan Hasil Belajar Kognitif Siswa. E-Jurnal Bioedutika. 3(2). 15-20. Diakses dari

http://journal.uad.ac.id/index.php/B IOEDUTIKA/article/view/4149/22 79

Schutte, N. S., Malouff, J. M., Hall, L. E., Haggerty, D. J., Cooper, J. T.m Golden, C. J., \& Dornheim, L. (1998). Development and validation of a measure of emotional intelligence. Personality and Inividual Differences. 167-177. http://doi.org/10.1016/S01918869(98)00001-4

Suryabrata, Sumadi, Proses Belajar di Perguruan Tinggi. Yogyakarta: Bumi_Aksara., 1989.
Soleha. (2018). Hubungan Antara Sikap Siswa dengan Prestasi Belajar Matematika Siswa Kelas V Sd Negeri Dipawangi. E-Jurnal PRISMA. 7(1). 113-122. Diakses dari https://jurnal.unsur.ac.id/prisma

Syarif, H. S. dan Haris M. (2017). Hubungan Kecerdasan Emosional dengan Hasil Belajar Siswa Kelas XI IPA SMA Negeri di Kota Parepare pada Mata Pelajaran Kimia. Jurnal Chemica. 18(1). 3947.

Doi: https://doi.org/10.35580/chemica.v $18 \mathrm{i} 1.4669$

Ventini, M., Hartati \& Moch. Soekardjo. (2018). Hubungan Kecerdasan Emosional dan Sikap Terhadap Pelajaran Matematika Dengan Hasil Belajar Matematika Siswa SMA Jakarta Timur. Jurnal Teknologi Pendidikan. 20(2). 167180. Diakses dari https://doi.org/10.21009/JTP2002.6 